JEL: D24; L60; 030

DOI:10.5937/industrija49-34376

UDC: 330.322:[338.45:620.282(497.11)"2010/2019"

339.727 .22

Original Scientific Paper

\title{
DOES FOREIGN INVESTMENT IMPROVE TECHNICAL EFFICIENCY OF MANUFACTURING? EVIDENCE FROM THE REPUBLIC OF SERBIA
}

\author{
Article history: \\ Received: 110ctober 2021 \\ Sent for revision: 13 October 2021 \\ Received in revised form: 18 October 2021 \\ Accepted: 18 October 2021 \\ Available online: 10 December 2021
}

\begin{abstract}
This paper offers significant evidence for the presence of a beneficial impact of foreign direct investment on technical efficiency based on a balanced panel data on a sample of 92 manufacturing groups over the period 2010-2019. Throughout this period Serbia lost $28 \%$ of the potential output of the manufacturing sector due to technical inefficiency. The finding is directly supported by the results at the level of the observed groups. Thus, the greatest increase in technical efficiency is in branches with a high share of foreign ownership, such as: production of motor vehicles, production of chemicals, and production of wire and cable equipment. The methodology is based on stochastic frontier analysis - within that, 'true' random effects model. The paper contributes to a better understanding of the possible consequences of foreigninvested enterprises on the domestic economy and, in particular, the performance of local businesses. As a result, it is helpful to policymakers in developing counties, where FDI is thought to have technological spillovers on native businesses.
\end{abstract}

Keywords: Technical Efficiency, Foreign direct investment (FDI), Stochastic frontier model, Serbian manufacturing

\footnotetext{
${ }^{1}$ Economics Institute a.d. Belgrade, ivan.nikolic@ecinst.org.rs
} 


\title{
Da li strane investicije popravljaju tehničku efikasnost prerađivačke industrije? Primer Republike Srbije
}

\begin{abstract}
Apstrakt: Na osnovu balansiranih panel podataka 92 grane prerađivačke industrije u periodu 2010-2019 ovaj rad pronalazi jake dokaze o postojanju pozitivnog uticaja stranih direktnih investicija na tehničku efikasnost. Usled tehničke nefikasnosti prerađivački sektor Srbije je u posmatranom periodu izgubio $28 \%$ potencijalnog autputa. Nalaz potkrepljuju dokazi na nivou pojedinačnih grana. Tako, najveći porast tehničke efikasnosti je zabeležen u granama industrije sa visokim udelom stranog vlasništva, poput: proizvodnje motornih vozila, proizvodnje hemikalija $i$ proizvodnje žičane $i$ kablovske opreme. Primenjena metodologija istraživanja se bazira na analizi stohastičke granice, odnosno, modelu "istinski" stohastičkih efekata. Rad doprinosi razumevanju potencijalnih efekata poslovanja firmi u stranom vlasništvu kako na ukupnu domaću privredu tako i na performanse lokalnih kompanija. Sledstveno, nalazi su korisni kreatorima politika zemalja u razvoju, koje su stava da SDI pospešuje tehničku efikasnost domaće privrede.
\end{abstract}

Ključne reči: Tehnološka efikasnost, strane direktne investicije (SDI), model stohastičke granice, prerađivačka industrija Srbije

\section{Introduction}

"The contribution of foreign direct investment (FDI) to the developing economies has been examined by a large body of theoretical and empirical studies. The key objective of this paper was to match the quantification of technical inefficiency with the high inflow of FDI that has been characteristic of Serbia in recent years and determine how FDI affects a firm's technical efficiency (TE) improvement as well as its technical progress in a stochastic frontier (SF) model" (Nikolić, 2020a. p. 71).

We should note that Serbia, in spite of the COVID-19 crisis, recorded a relatively high FDI inflow of EUR 3.0 bn gross (6,4\% of GDP) in 2020 , too. FDI inflows, which were $13 \%$ higher than the five-year average and $41 \%$ higher than the ten-year average, remained broadly scattered and, as previously, mostly channeled to export-oriented industries, covering the current account deficit completely (NBS, 2021). 


\section{Literature review}

In the literature, the relationship between FDI and productivity/efficiency has been hotly disputed. Many endogenous growth models supported the notion that FDI boosts TFP and so boosts economic growth. However, to the author's knowledge, there was just one paper that looked at the impact of FDI on the TE of the manufacturing sector in Serbia up until 2021 (Nikolić, 2020b). From that aspect this paper can certainly be considered original.

Since this paper studies TE and effects of FDI by applying SF model in the manufacturing industry it maybe useful to provide a brief review of the extant literature in the same context. Vu (2016), for example, used the SF model to calculate the TE of FDI firms in the Vietnamese manufacturing sector from 2009 to 2013. The average TE of FDI enterprises is around $60 \%$, which is greater than the average TE of domestic firms (including private firms and state-owned firms). Wang and Wong (2012) used unbalanced panel data from a 77-country sample from 1986 to 2007 to show that FDI and imported foreign R\&D have a considerable impact on the TE of domestic countries. Fedorova et al. (2019) on a sample of more than 33.000 Russian firms concluded that companies with FDI are characterized with a higher level of efficiency compared to companies without foreign capital.

Simultaneously, many studies empirically examines relationship between FDI spillovers and TE of domestic firms. According to Sur and Nandy (2018), FDI efficiency spillovers in the Indian automobile industry have a favorable impact on domestic business productivity from 2001 to 2014, and foreign firms are more technically efficient than domestic enterprises. Keshary (2013) on a sample of 177 firms for 7 years covering FY 2000/01 to FY 2006/07 found that the foreign affiliates of multinational enterprises as a ownership group maintains higher level of TE than domestic firms even after controlling for the additional determinants (both observed and unobserved) of TE. Likewise, the empirical results from the SF of Suyanto and Salim (2013) showed that foreign firms are more efficient than domestic competitors, and the presence of the former increases the inefficiency of the latter. These uthors received an even more detailed finding a year later. A panel data SF method is applied to 3318 Indonesian firms surveyed over the period 1988-2000. The findings show that FDI has a favorable impact on TE. When the samples are separated into two efficiency levels, however, interesting disparities appear. In general, negative spillovers are experienced by high-efficiency domestic enterprises, while positive spillovers are experienced by low-efficiency firms. These findings support the efficiency gap hypothesis, which states that the wider the gap between domestic and foreign enterprises, the easier it is for the former to derive spillover advantages from the latter (Suyanto et al, 2014). 
Empirical studies have also yielded contradictory results regarding the spillover benefits from FDI. For example, Vu and Van Hang (2017) found positive vertical spill-over effects but no horizontal spill-over effects in firm-level panel data on the Vietnamese wearing apparel industry from 2009 to 2013. Furthermore, the absorptive capacity of domestic enterprises has a detrimental impact on the gains derived from FDI externalities, according to this study. Wang and Wong (2016) used data from more than 12.000 Chinese manufacturing firms (twodigit level industries in the manufacturing sector over 2002 to 2004) and discovered that FDI in a company's own industry (horizontal FDI) did not always boost its TE. However, firms with a larger absorptive capacity tend to benefit more from horizontal FDI than others. They also found that foreign presence in a firm's downstream industries helps improve the firm's TE, while foreign presence in upstream industries does not. The results of Wiboonchutikula et al. (2016) provide no evidence on spillover effects of the FDI in horizontal industries on either the TFP or TE of domestic firms. While FDI in upstream sectors has negative spillover effects on firms in all industry groups, FDI in downstream industries has positive and large spillover effects.

Following Jiang (2012) in China from 1981 to 2004 the FDI technical efficiency exhibits a U-shaped time pattern, i.e., there is efficiency deterioration in the early stage of China's reform and a gradual efficiency improvement after the mid-1990s. The results from the Phan and Ngo (2012) estimations reveal that, foreign firms, in general, are not necessarily more efficient than domestic enterprises, depending on the types of ownership collaboration between domestic and foreign enterprises, as well as sub-industries. To be more specific, state-owned companies with foreign partners in the food and beverage, textiles, apparel, and footwear, and energy and chemical sectors are more efficient than other ownership partnerships. The author's Hanousek et al. (2012) findings are interesting, too. They employed a panel version of a SF model for the period 1996-2007 on more than 190,000 Czech firms and discovered that concentration and foreign ownership are linked to efficiency, and that FDI has favorable microeconomic benefits. They do, however, illustrate that a simple majority is not always the ideal structure for increasing efficiency.

\section{Model specification and methodology}

The work on measurement through frontier models began in the late 1970 s by Aigner et al (1977) and Meeusen and van den Broeck (1977). Since then, major contribution comes from Battese and Coelli (1985; 1988), Green (2005a; 2005b) and Kumbhakar et al. (2002; 2015). 
In this paper, the methodology is based on 'true' random effects - TRE model (Greene, 2005a; 2005b). The model allows the separation of time-invariant unnoticed heterogeneity from the inefficiency component, which changes over time. For that reason, Greene, in accordance with the assumptions about unnoticed unit-specific heterogeneity in front of the word stochastic, added the adjective "true".

His TRE model is specified as:

$$
y_{i t}=\left(\alpha+\omega_{i}\right)+\boldsymbol{\beta}^{\prime} \boldsymbol{x}_{i t}+v_{i t}-u_{i t}
$$

with distribution assumptions:

$$
\begin{gathered}
\omega_{i} \sim N\left[0, \sigma_{\omega}^{2}\right] \\
u_{i t} \sim N^{+}\left[0, \sigma_{i t}^{2}\right]=N^{+}\left(0, \exp \left(\omega_{u 0}+z_{u, i t}^{\prime} \omega_{u}\right)\right) \\
v_{i t} \sim N\left[0, \sigma_{v}^{2}\right]
\end{gathered}
$$

where $y_{i t}$ is the log of output (in this paper, value added) for manufacturing group $i$ at time $t, \alpha$ is a common intercept; $\omega_{i}$ is a time invariant, manufacturing group specific random term meant to capture cross group heterogeneity; $\boldsymbol{x}_{i t}$ is the vector of inputs (in logs); $\boldsymbol{\beta}$ is the associated vector of technology parameters to be estimated; $v_{i t}$ is a random two-sided noise term (exogenous production shocks) that can increase or decrease output (ceteris paribus); and $u_{i t}$ is the non-negative one-sided inefficiency term.

Due to the inclusion of unobserved heterogeneity term $\omega_{i}$, TRE model has advantages over 'basic' SF models - it controls for any omitted variable biases and also avoids heterogeneity biases in the estimates of technical inefficiency.

The Greene model's parameters are determined using the maximum simulated likelihood method because to its complexity. The Jondrow et al. (1982) (JLMS) result can then be used to estimate residual technical inefficiency:

$$
\hat{u}_{i t}=E\left[u_{i t} \mid \varepsilon_{i t}\right]=\frac{\sigma \lambda}{1+\lambda^{2}}\left[\frac{\phi\left(a_{i t}\right)}{1-\phi\left(a_{i t}\right)}-a_{i t}\right]
$$

where $=\frac{\sigma_{u}}{\sigma_{v}}$ and $\sigma=\sqrt{\sigma_{v}^{2}+\sigma_{u}^{2}}$. It is obvious that $\lambda$ is an indicator of relative variability of the sources of variation (i.e. inefficiency and statistical noise). A value of $\lambda>1$ implies that the discrepancy between the observed and maximum attainable level of output is dominated by variability emanating from technical inefficiency. On the other hand variance parameter $\sigma$ indicates whether conventional production function would be a satisfactory representation of the data used or not.

We underline that the main goal of SF models is not only to serve as a standard against which manufacturers' TE is estimated, but also to investigate how 
exogenous variables (in this case, foreign ownership) influence the manufacturer's performance.

Namely, according to Battese and Coelli (1985) the technical inefficiency effect, $u_{i}$, in the SF model (1) are assumed to be a function of a set of explanatory variables associated with inefficiency of units over time:

$$
u_{i t}=z_{i t} \delta+w_{i t}
$$

where $z_{i t}$ is vector of variables which may influence the efficiency of units, $\delta$ is vector of unknown parameters to be estimated and $w_{i t}$ are unobservable random variables which are assumed to be independently distributed and obtained by truncation of the normal distribution with zero mean and constant variance.

\section{Data}

This "empirical analysis utilises the balanced panel data on a sample of 92 Groups of Section C 'Manufacturing' (NACE Rev. 2 at 3-digit level), spread over 10 years period 2010-2019 (see Table 1). The data source is the Business Register of Statistical Office of the Republic of Serbia. The SF model estimates a firm's production frontier given a set of production inputs. The deviation of a firm's actual output level from its maximum level of output is defined as technical inefficiency. The variable FDI (share of foreign ownership) was used as a covariate" (Nikolić, 2020a, p.71).

Tabel 1. Summary statistics for variable used in the estimation of TRE model

\begin{tabular}{c|rrrrr}
\hline Variable & \multicolumn{1}{|c}{ Obs } & \multicolumn{1}{c}{ Mean } & Std. Dev. & \multicolumn{1}{c}{ Min } & \multicolumn{1}{c}{ Max } \\
\hline t & 920 & 2014,5 & 2,9 & 2010 & 2019 \\
VA & 920 & 50604,5 & 72784,3 & $-91341,1$ & 627662,4 \\
K & 920 & 118515,1 & 196473,6 & 0 & 2254966,0 \\
L & 920 & 27696,1 & 31958,9 & 12,5 & 288688,8 \\
M & 920 & 115944,8 & 176279,2 & 0,2 & 1404700 \\
E & 920 & 9540,1 & 18933,6 & 2,7 & 297690,8 \\
FDI & 920 & 29,1 & 26,3 & 0,0 & 100,0 \\
\hline \multicolumn{5}{c}{ Source: Author's Calculation }
\end{tabular}


A description of the other variables follows below:

- $\quad$ VA (value added): The gross value added at basic price is defined as the difference between output at basic prices and intermediate consumption at purchaser's prices (in EUR thousand);

- $\quad \mathrm{K}$ : Capital (in EUR thousand);

- $\quad \mathrm{L}$ (labor costs): encompass salaries, wages and other personal indemnities (in EUR thousand);

- $\quad M$ (material inputs): row material costs (in EUR thousand);

- $\quad E$ (energy inputs): fuel and energy costs (in EUR thousand).

\section{Results}

Under certain assumptions, the coefficients are estimated in such a way as to maximize the reliability function (Kumbhakar and Lovell, 2000), by complex iterative procedures (with the help of the statistical program STATA).

The $\lambda$ - parameter is significantly greater than zero in all specifications, showing that inefficiency effects occur. Furthermore, we use a generalised likelihood ratio test for the null hypothesis of no one-sided error to check for the presence of $u_{i t}$ in the model. The test is based on the loglikelihood (LR) values of the OLS (the restricted model) and the TRE model (the unrestricted model given in equation 1$)^{2}$. Although the LR test value for each sprification are 335,$87 ; 332,04$ and 315,64 , respectively we strongly reject the null hypothesis in all sprifications confirming the existence of inefficiency effects and that applying the average response function with just $v_{i t}$ error term is not appropriate.

Table 2. Estimated TRE model

\begin{tabular}{|c|c|c|c|}
\hline \multirow{2}{*}{$\begin{array}{c}\ln \boldsymbol{V A} \\
\text { (dep. variable) }\end{array}$} & \multicolumn{3}{|c|}{ Model specifications } \\
\hline & 1. & 2. & 3. \\
\hline \multicolumn{4}{|c|}{ Stochastic frontier } \\
\hline _Cons & $\begin{array}{c}-28,651^{\star \star *} \\
(4,7164)\end{array}$ & $\begin{array}{c}-30,713^{\star \star *} \\
(4,9764)\end{array}$ & $\begin{array}{c}-32,835^{\star * *} \\
(6,0361)\end{array}$ \\
\hline$t$ & $\begin{array}{l}0,016^{* * *} \\
(0,0023)\end{array}$ & $\begin{array}{l}0,017^{* * *} \\
(0,0025)\end{array}$ & $\begin{array}{l}0,018^{* * *} \\
(0,0030)\end{array}$ \\
\hline $\ln K$ & $0,277^{* * *}$ & $0,237^{* * *}$ & $0,231^{* * *}$ \\
\hline
\end{tabular}

\footnotetext{
2 The LR test is equal to $-2\left[\mathrm{~L}\left(H_{0}\right)-\mathrm{L}\left(H_{1}\right)\right]$ where $\mathrm{L}\left(H_{0}\right)$ and $\mathrm{L}\left(H_{1}\right)$ are the log-likelihoods of the restricted and unrestricted models respectively. Tables by Kodde and Palm (1986) provide the crucial values.
} 


\begin{tabular}{|c|c|c|c|}
\hline & $(0,0299)$ & $(0,0296)$ & $(0,0280)$ \\
\hline \multirow[t]{2}{*}{$\ln L$} & $0,507^{* * *}$ & $0,417^{\star \star *}$ & $0,292^{\star * *}$ \\
\hline & $(0,0319)$ & $(0,0384)$ & $(0,0416)$ \\
\hline \multirow[t]{2}{*}{$\ln M$} & - & $0,118^{\star \star \star}$ & $0,110^{\star \star *}$ \\
\hline & & $(0,0201)$ & $(0,0303)$ \\
\hline \multirow[t]{2}{*}{$\ln E$} & - & & $0,129^{\star \star \star}$ \\
\hline & & & $(0,0339)$ \\
\hline \multicolumn{4}{|c|}{ Technical unefficiency (effect) ${ }^{1}$} \\
\hline \multirow[t]{2}{*}{ FDI } & $-0,033^{\star \star \star}$ & $-0,035^{\star \star \star}$ & $-0,033^{\star \star \star}$ \\
\hline & $(0,0057)$ & $(0,0059)$ & $(0,0058)$ \\
\hline \multirow[t]{2}{*}{$\theta$} & $1,117^{* * *}$ & $1,165^{\star \star \star}$ & $0,999^{\star * *}$ \\
\hline & $(0,0284)$ & $(0,0309)$ & $(0,2786)$ \\
\hline \multirow[t]{2}{*}{$\sigma_{u}$} & $0,822^{* * *}$ & $0,815^{\star \star *}$ & $0,797^{\star * *}$ \\
\hline & $(0,0386)$ & $(0,0388)$ & $(0,0389)$ \\
\hline \multirow[t]{2}{*}{$\sigma_{v}$} & $0,087^{\star * *}$ & $0,095^{\star \star \star}$ & $0,101^{* * *}$ \\
\hline & $(0,0115)$ & $(0,0106)$ & $(0,0112)$ \\
\hline \multirow[t]{2}{*}{$\lambda$} & $9,470^{\star * *}$ & $8,539^{\star \star *}$ & $7,844^{* * *}$ \\
\hline & $(0,0423)$ & $(0,0424)$ & $(0,0429)$ \\
\hline
\end{tabular}

Notes: ${ }^{1}$ value calculated as the sample mean; the standard error value is given in parentheses, ${ }^{* * *}$ denotes significance at $1 \%$

Source: ibidem

Summing up, given the results in Table 2:

All coefficients have the desired sign and are statistically significant at $1 \%$ statistical level.

The coefficient with $\mathrm{t}(0.016-0,018)$ implies that from 2010 to 2019 , the average productivity growth (ie value added for a given level of capital and engaged labor force) was $1,7 \%$ per year. This would imply that technical change played a key role in the industrial sector's productivity increase in Serbia.

The inclusion of the FDI variable in the model is also justified. A negative sign was obtained, which means that with the decrease of the share of foreign ownership in the total capital of the manufacturing, the technical inefficiency increases. The above results also indicate that the presence of foreign ownership in the same manufacturing group seems to enhance the TE of domestic firms, too. 
Table 3. Average technical efficiency estimates, 2010-2019. via $\exp (-E(s \cdot u \mid \varepsilon))$

\begin{tabular}{c|ccccc}
\hline Model Spec. & Obs & Mean & Std.Dev. & Min & Max \\
\hline 1. & 899 & 0,7165 & 0,1968 & 0,0045 & 0,9712 \\
\hline 2 & 899 & 0,7209 & 0,1944 & 0,0074 & 0,9716 \\
\hline 3 & 899 & 0,7208 & 0,1905 & 0,0365 & 0,9709 \\
\hline
\end{tabular}

The summary statistics of estimated TE scores (Table 3) indicate that Serbia from 2010 to 2019 lost around $28 \%$ of the potential output of the manufacturing sector due to technical inefficiency.

The findings are directly confirmed by the results at the level of the manufacturing sector's observed groupings. The largest gains in technical efficiency can be seen in industries with a high percentage of foreign ownership, such as automobile manufacturing, chemical manufacturing, and wire and cable manufacturing.

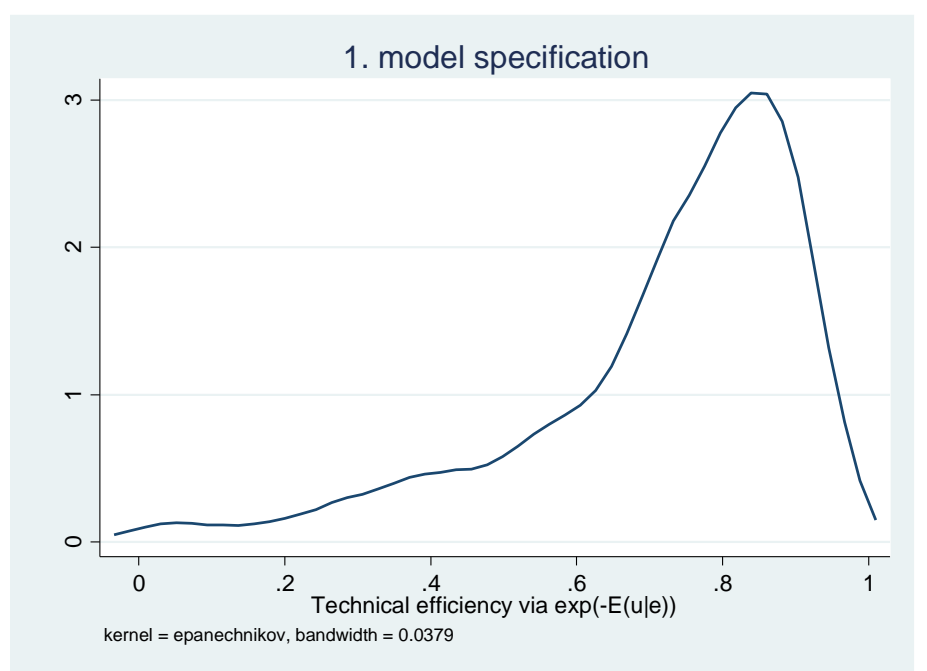

Industrija, Vol.49, No.2, 2021 


\section{Model specification}

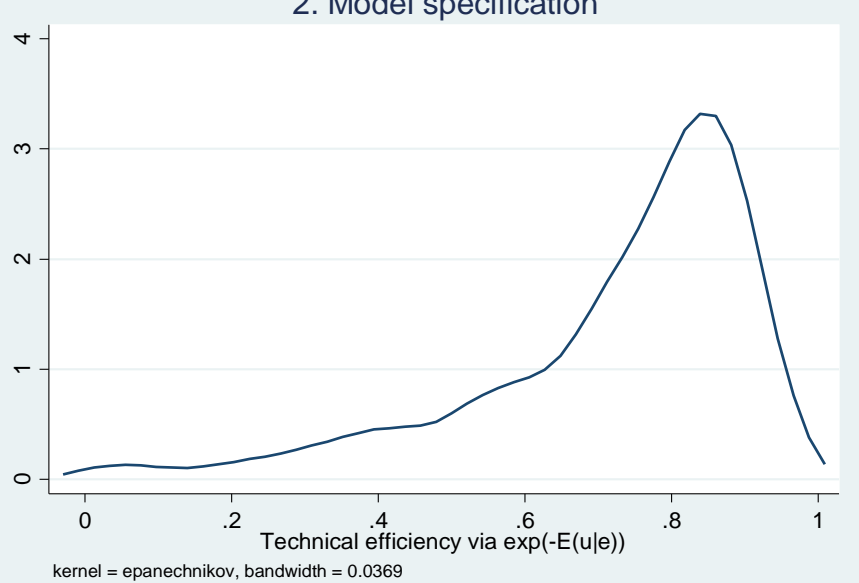

3. Model specification

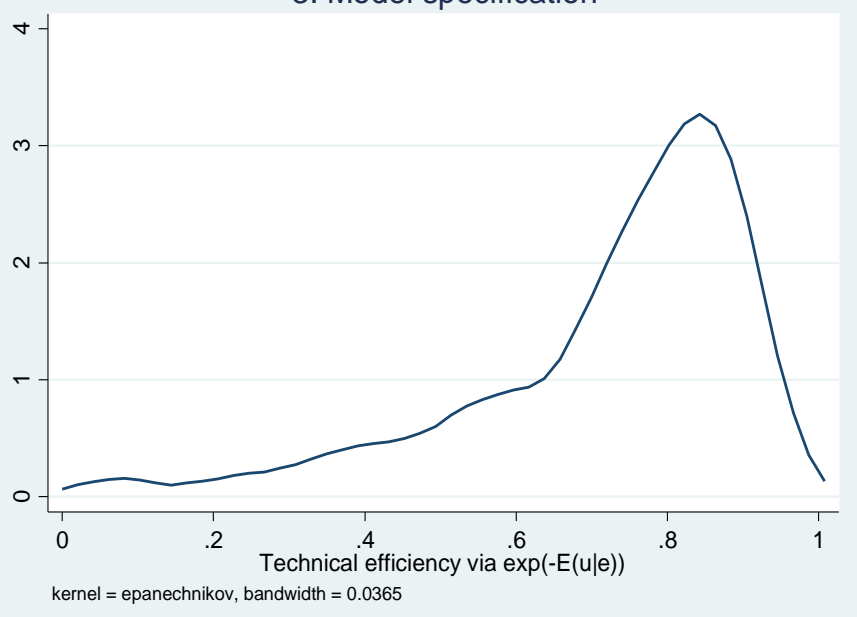

Figure 1. Kendel density estimate Source: ibidem

The figure 1 shows Kernel density distribution of technical efficiency for for all three specifications. 


\section{Conclusion}

Many initiatives have been taken by Serbian policymakers in the recent decade to attract FDI, with the hope that this inflow will drive export-led growth, increase employment, improve productivity, and accelerate growth. The foregoing findings suggest that foreign enterprises' presence in Serbia has a favorable impact on the indigenous industry's technological efficiency in general. However, we must be cautious, because the impacts of FDI vary by industry, and a "one-size-fits-all" investment promotion program is not suggested.

The paper contributes to a better understanding of the possible consequences of foreign-invested enterprises on the domestic economy and, in particular, the performance of local businesses. As a result, it is helpful to policymakers in developing counties, where FDI is thought to have technological spillovers on native businesses.

\section{References}

Aigner, D.J., Lovell, C.A.K., \& Sehmidt, P. (1977). Formulation and estimation of stochastic frontier production function models. Journal of Econometrics 6(1), 21-37.

Battese, George E., \& Coelli, Timothy. (1985). A model for technical inefficiency effects in a stochastic frontier production function for panel data, Journal of Econometrics, 20, 325-332

Battese, George E., \& Coelli, Timothy (1988). Prediction of firm-level technical efficiencies with a generalized frontier production function and panel data. Journal of Econometrics, 38 (3), 387-399.

Fedorova, Elena A., Nikolaev, Aleksei E., Shirokova, Yuliya S. and Fedorov, Fedor Yu. (2019). Export and Import Activities of Russian Companies with FDI in the Context of Sanctions, Finansovyj žhurnal - Financial Journal, issue 3, p. 75-90.

Greene, W.H. (2005a). Fixed and Random Effects in Stochastic Frontier Models. Journal of Productivity Analysis, 23, 7-32.

Greene, W.H. (2005b). Reconsidering heterogeneity in panel data estimators of the stochastic frontier model. Journal of Econometrics 126, 269-303

Hanousek, Jan, Kočenda, Evžen and Masika, Michal (2012). Firm Efficiency: Domestic Owners, Coalitions, and FDI, CERGE-EI Working Papers, The Center for Economic Research and Graduate Education Economics Institute, Prague.

Jiang, Mingming (2012), On the Performance of Foreign Direct Investment in China: 1981-2004, Economics Bulletin, 32, issue 4, p. 3320-3332. 
Jondrow, J., Materov, I., Lovell, K., Schmidt, P. (1982). On the estimation of technical inefficiency in the stochastic frontier production function model. Journal of Econometrics 19 (2/3), 233-238.

Keshari, Pradeep (2013). Efficiency spillovers from FDI in the Indian machinery industry: a firm-level study using panel data models, MPRA Paper, University Library of Munich, Germany.

Kodde, D.A. and Palm, F.C. (1986). Wald Criteria for Jointly Testing Equality and Inequality Restrictions. Econometrica, 54, 1243-1248.

Kumbhakar, \& Lovell. (2000). Stochastic Frontier Analysis. Cambridge UK: Cambridge University Press, pp. 343

Kumbhakar, S.C., Denny, M., \& Fuss, M. (2000). Estimation and decomposition of productivity change when production is not efficient: a panel data approach. Econometric Reviews, 19(4), 312-320.

Kumbhakar, Wang, \& Horncastle. (2015). A Practitioner's Guide to Stochastic Frontier Analysis Using Stata, Cambridge University Press, pp. 556.

Meeusen, W., and J. van den Broeck. (1977). Efficiency estimation from CobbDouglas production functions with composed error. International Economic Review 18: 435-444.

National Bank of Serbia, Inflation Report - February 2021, p. 27

Nikolić, I. (2020a). FDI contribution to technical efficiency in the serbian manufacturing sector, p. 71-73, in: Emerging Trends in Business Economics: Towards Competitiveness, Digitalization and Financial Innovation - Book of Abstracts, ed. Ljumović, I., Simović, V., \& Marjanović, D., $13^{\text {th }}$ International Scientific Conference, Institute of Economic Sciences, ISBN 978-86-89465-56-3

Nikolić, I. (2020b). Tehnička (ne)efikasnost prerađivačke industrije Srbije u periodu 2010-2018 - kakav je efekat stranih investicija? str. 174-190, u: IZAZOVI održivog razvoja u Srbiji i Evropskoj uniji, Institut društvenih nauka, Beograd, 319 str. ISBN 978-86-7093-237-1

Phan, Lien and Ngo, Quang - Thanh (2012). Do FDI enterprises work more efficiently than domestic ones in Vietnam? Evidence from panel data analysis, No 24, Working Papers, Development and Policies Research Center (DEPOCEN), Vietnam.

Sur, Abhisek and Nandy, Amarendu (2018). FDI, technical efficiency and spillovers: Evidence from Indian automobile industry, Cogent Economics \& Finance, 6, issue 1.

Suyanto, Suyanto and Salim, Ruhul (2013). Foreign direct investment spillovers and technical efficiency in the Indonesian pharmaceutical sector: firm level evidence, Applied Economics, 45, issue 3, p. 383-395.

Suyanto, Suyanto, Salim, Ruhul and Bloch, Harry (2014). Which firms benefit from foreign direct investment? Empirical evidence from Indonesian manufacturing, Journal of Asian Economics, 33, issue C, p. 16-29. 
Vu, Duong and Van Hung, Le. (2017). FDI Spill-Overs, Absorptive Capacity and Domestic Firms' Technical Efficiency in Vietnamese Wearing Apparel Industry, Acta Universitatis Agriculturae et Silviculturae Mendelianae Brunensis, 65, issue 3, p. 1075-1084.

$\mathrm{Vu}$, Duong (2016). Technical efficiency of FDI firms in the Vietnamese manufacturing sector, Review of Economic Perspectives, 16, issue 3, p. 205-230.

Wang, Miao and Wong, M. C. Sunny. (2012). International R\&D Transfer and Technical Efficiency: Evidence from Panel Study Using Stochastic Frontier Analysis, World Development, 40, issue 10, p. 1982-1998.

Wang, Miao and Wong, M. C. Sunny. (2016). Effects of Foreign Direct Investment on Firm-level Technical Efficiency: Stochastic Frontier Model Evidence from Chinese Manufacturing Firms, Atlantic Economic Journal, 44, issue 3, p. 335-361.

Wiboonchutikula, Paitoon, Phucharoen, Chayanon and Pruektanakul, Nuchit (2016). Spillover effects of foreign direct investment on domestic manufacturing firms in Thailand. The Singapore Economic Review (SER), 61, issue 02, p. 1-32. 